\title{
Pengaruh Tindakan Perawatan Luka Terhadap Proses Penyembuhan Luka Ulkus Diabetikum Pada Pasien Dm Di Puskesmas Kota Rantauprapat
}

\section{The Effect Of Wound Care Measures On The Healing Process Of Diabetic Ulcer Wounds In Diabetes Mellitus (DM) Patients At Rantauprapat Health Center}

\author{
Eva Haryana Elisa Panjaitan ${ }^{1(\mathrm{k})}$, Thomson P Nadapdap ${ }^{(2)}$, Linda Hernike ${ }^{(3)}$ \\ ${ }^{1}$ Kebijakan Manajemen Pelayanan Kesehatan, Institut Kesehatan Helvetia, Medan, Indonesia \\ ${ }^{2.3}$ Institut Kesehatan Helvetia, Medan, Indonesia \\ Email Penulis Korespondensi ${ }^{(1)}$, evapjt@yahoo.com
}

\begin{abstract}
Abstrak
Diabetes melitus menjadi masalah kesehatan masyarakat yang serius dan terus berkembang secara global. Penderita Diabetes melitus yang mengalami luka di kaki sangat memerlukan teknik perawatan luka yang benar agar tidak terjadi amputasi. Tujuan peneliti ini untuk Mengetahui pengaruh perawatan luka dengan modern dressing terhadap proses penyembuhan luka ulkus diabetikum pada penderita diabetes melitus (DM) di puskesmas kota Rantau Prapat. Penelitian ini menggunakan disain penelitian deskriptif kualitatif yang dilakukan dengan pendekatan wawancara. Informan dalam penelitian ini adalah penderita diabetes melitus yang mengalami luka ulkus diabetikus sebanyak 2 orang dan 4 tenaga kesehatan. Analisa data dalam penelitian ini menggunakan analisa deskriptif kualitatif. Dari hasil penelitian dikertahui bahwa pengetahuan tentang cara perawatan luka masih rendah, sikap takut dan khawatir informan, sehingga tidak disiplin darang ke puskesmas sesuai jadwal yang telah ditentukan serta pendidikan dan fasilitas kesehatan sangat memengaruhi tindakan mengobati luka secara konvensional dan perawatan luka modern.
\end{abstract}

Kata kunci : Diabetes Melitus, Pengetahuan, Sikap dan Fasilitas Pengobatan

\begin{abstract}
Diabetes mellitus is a serious problem and continues to grow globally. Diabetes mellitus sufferers who experienced injuries to their feet really need proper wound care techniques to avoid amputation. . The study aimed to determine the effect of wound care measures on the healing process of diabetic ulcer wounds in diabetes mellitus (DM) patients at the Rantau Prapat city health center. This study used a qualitative descriptive research design conducted with an interview approach. There were 6 informants consisting of 2 informants with diabetic ulcer wounds, 4 health workers. Data analysis used a qualitative descriptive analysis. From the results of the study was known that knowledge of how wound care is still low, the attitude of informants is afraid and worried so that they are not disciplined in coming to the health center according to the predetermined schedule, as well as education and also health facilities greatly influence the act of treating wound with conventionally and with care modern wounds.
\end{abstract}

Key words: Diabetes mellitus, Knowledge, Attitudes and Treatment Facilities

http://ejournal.urindo.ac.id/index.php/kesehatan

Article History :

Sumbitted 04 Februari 2021, Accepted 29 Juni 2021, Published 30 Juni 2021 


\section{PENDAHULUAN}

Diabetes melitus menjadi masalah kesehatan masyarakat yang serius dan terus berkembang secara global. Penyakit ini turut menambah angka mortalitas, morbiditas dan ketunadayaan dini yang signifikan, serta kehilangan tahun kehidupan yang potensial. Lebih dari $7 \%$ populasi individu dewasa di Australia menyandang diabetes melitus. Namun, prevelensi meningkat menjadi 23\% pada individu berusia 75 tahun atau lebih dan diperkirakan sebesar 10\% hingga 30\% pada masyarakat aboringin, penduduk dari kepulauan pasifik,serta sebagian negara Asia (1). DiSelandia Baru, angka prevelensi diabetes melitus pada populasi dewasa keturunan eropa adalah 3,1\% yang lebih dari 8\% diantaranya merupakan keturunan Maori dan kepulauan pasifik. Indonesia, sebagai salah satu negara berkembang, menempati urutan keempat dalam jumlah penderita diabetes melitus terbesar didunia. Sementara, berdasarkan data International Diabetetic Federation (IDF), indonesia menempati urutan ke-9 dengan angka kasus diabetes mellitus dan diprediksikan naik ke peringkat 6 pada tahun 2030 dengan 12 juta kasus (2). Diabetes telah merenggut nyawa 5 juta orang dewasa di tahun 2015. Angka penderita diabetes yang didapat di Asia Tenggara adalah Singapura $12.8 \%$, Thailand $8 \%$, Malaysia 16.6 \% dan Indonesia 6,2 \% (IDF 2015). Pada saat ini, dilaporkan bahwa kota-kota besar seperti Jakarta dan Surabaya, sudah hampir $10 \%$ pendududknya mengidap diabetes.

Diabetes jelas mengakibatkan beban ekonomi yang tidak sedikit, lebih-lebih jika penderitaannya telah telah terkena komplikasi. Tanpa pengobatan yang baik, Diabetes akan menyerang banyak organ penting dalam tubuh, bahkan bisa berakibat fatal. Estimasi sepuluh persen biaya kesehatan dihabiskan untuk urusan diabetes. Di negaranegara pasifik barat (termasuk Indonesia) 2015, IDF melaporkan 106-191 trilun dolar Amerika dihabiskan berobat diabetas. Dengan obat generik dan pemeriksaan laboratorium sederhana, pasien diabetes di negara Indonesia di tafsir menghabiskan rata-rata 300-500 ribu rupiah untuk berobat. Biaya ini belum menghitung dampak dampak sosial dan ekonomi karena penderita tidak mampu bekerja dan sebagainya.

Berdasarkan data dari rekam medis RSU Dr. Pirngadi Kota Medan (2019) diketahui bahwa jumlah penderita diabetes melitustipe 2 pada tahun 2017 adalah sebanyak 1.321 orang, tahun 2018 sebanyak 1.112 orang dan tahun 2019 meningkat menjadi 1.832 orang (3). Labuhan batu mencatat sekitar 2.734 orang yang menderita diabetes melitus (DM) pada tahun 2017 data ini meningkat pada tahun 2019 sebanyak 2.954 orang. (Sumber data PTM puskesmas Kota 
Rantauprapat,2019). Puskesmas kota Rantau Prapat pada tahun 2017 tercatat 97 orang penderita diabetes melitus dan tahun 2018 sebanyak 103 orang serta pada tahun 2019 meningkat menjadi 132 orang yang menderita diabetes melitus (DM).

Penderita Diabetes melitus yang mengalami luka di kaki sangat memerlukan perawatan luka yang dapat membantu penyembuhan luka dengan benar agar tidak terjadi amputasi. Perawatan luka telah berkembang secara pesat saat ini. Pada teknik perawatan luka konvensionall, luka ditutup dengan kain kassa dengan tipe kering atau basah kering. Proses penyembuhan luka dengan teknik ini akan lebih lama. Karena perawatan yang dilakukan hanya membungkus luka di bagian dalam, tanpa melihat proses perkembangan luka. Sehingga kondisi luka akan lebih parah, penyembuhan akan lebih lama, dan sering terjadi komplikasi atau dilakukan amputasi. Pada teknik perawatan luka modern,luka dipertahankan dalam kondisi lembab (4).

Dengan perawatan luka yang di gunakan di puskesmas kota Rantau Prapat penulis melihat perawatan luka yang di lakukan saat ini masih menggunakan perawatan luka konvensional krn kassa sebagai dressing utama. Dalam perawatan luka saat ini sudah ada perawatan luka moderen yang menggunakan balutan atau dressing moderen juga seperti primer dressing dan sekunder dressing sebagai balutan utama dengan perinsip lembab atau moist.

Perawatan luka yang diberikan pada pasien harus dapat meningkatkan proses penyembuhan luka. Metode perawatan luka dikenal 2 macam, yaitu konvensional dan modern dressing. Metode perawatan modern, dalam menciptakan suasana lembab menggunakan modern dressing, misalnya dengan $\mathrm{Ca}$ alginat atau hydrokoloid. Sedangkan, pada cara perawatan luka konvensional memerlukan kasa sebagai balutan dan $\mathrm{NaCl}$ untuk membasahi. Kemudian luka dikompres kasa lembab dan diganti sebelum kasa mengering (4).

Modern wound dressing merupakan salah satu metode perawatan luka dengan cara tertutup dan lembab yang difokuskan untuk menjaga luka dari dehidrasi dan meningkatkan proses penyembuhan luka. Luka dengan suasana lembab dapat mempercepat fibrinolisis, angiogenesis, menurunkan resiko infeksi, pembentukan growth factor, dan pembentukan sel aktif. Modern wound dressing yang mengandung antimikroba efektif membunuh bakteri dan jamur pada luka, mencegah infeksi berulang selama penyembuhan dan efektif untuk pengobatan luka yang terinfeksi (5).

Pemilihan modern dressing pada pasien pressure ulcer tergantung dari stadium 
luka tekan serta jumlah eksudat. Terapi pelengkap sering disebut dengan terapi adjuvant atau terapi komplementer saat ini ramai dibicarakan. Salah satunya adalah terapi ozon. Efek medis ozon sudah diketahui sejak abad ke-19. Hingga saat ini, penggunaan ozon baik secara sistemik berupa autohemoterapi maupun topikal telah diaplikasikan untuk membantu penyembuhan luka seperti luka bakar, luka tembak, luka terinfeksi, ulkus gangren diabetikum, ulkus dekubitus, luka post operasi dan lain-lain (6).

Keadaan kaki diabetik lanjut yang tidak ditangani secara tepat dapat berkembang menjadi suatu tindakan pemotongan amputasi kaki. Adanya luka dan masalah lain pada kaki merupakan penyebab utama kesakitan morbiditas, ketidakmampuan disabilitas, dan kematian mortalitas pada seseorang yang menderita diabetes melitus . Komplikasi yang paling sering dialami pengidap diabetes adalah komplikasi pada kaki sebanyak $15 \%$ yang kini disebut kaki diabetes (7).

\section{METODE PENELITIAN}

Penelitian ini menggunakan disain penelitian deskriptif kualitatif yang dilakukan dengan pendekatan wawancara. Dengan tujuan utama membuat gambaran atau deskriptif tentang suatu keadaan secara objektif, baik yang berupa faktor resiko maupun efek atau hasil. Data hasil penelitian ini disajikan apa adanya (objektif) (8). Penelitian ini dilakukan di puskesmas Kota Rantau Prapat kabupaten Labuhan batu. Subyek yang dipilih dalam penelitian ini dibagi dalam dua katagori yaitu informan utama dan informan trigangulasi. Karakter informan utama adalah penedrita DM yang mengalami luka ulkus diabetikum yang pernah berobat ke puskesmas Kota RantauPrapat sebanyak 2 orang, sedangkan informan tiangulasi adalah pasien,keluarga dan petugas kesehatan. Pengumpulan data kualitatif dilakukan dengan bekerja dalam memilah-milah data untuk menjadi satuan data yang dapat dikelola,mensentesiskannya, mencari dan menentukan pola serta menemukan apa yang penting dengan apa yang dipelajari dan memutuskan apa yang bisa di ceritakan kepada orang lain (9).

\section{HASIL PENELITIAN}

Variabel yang di analisis adalah pengetahuan, sikap, pendidikan dan fasilitas kesehatan dalam perawatan luka. Adapun pun kesimpulan indepth interview dapat dilihat pada tabel di bawah ini. 
Tabel 1

Hasil Kesimpulan Indepth Interview Pengetahuan tentang Perawatan Luka

\begin{tabular}{|c|c|c|c|c|}
\hline No. & Nama Informan & Umur & Pendidikan & Keterangan \\
\hline 1. & SM (Pasien) & 48 & SMA & $\begin{array}{l}\text { Luka dipecahkan dengan jarum pentol yang diberi } \\
\text { betadin. }\end{array}$ \\
\hline 2. & M (Pasien) & 45 & DIII & Luka di oles salep dari dokter \\
\hline 3. & M (Perawat IGD) & 47 & SPK & Perawatan luka konvensional \\
\hline 4. & M (Perawat IGD) & 41 & S1 & Perawatan luka moderen \\
\hline 5. & D (Dokter Koordinator) & - & S1 & Perawatan luka yaitu konvensional dan moderen \\
\hline 6. & Y (Kepala Puskesmas) & - & S1 & $\begin{array}{l}\text { Perawatan luka di serahkan kepada dokter dan } \\
\text { perawat }\end{array}$ \\
\hline
\end{tabular}

Tabel 2

Hasil Kesimpulan Indepth Interview Sikap tentang Perawatan Luka

\begin{tabular}{lllll}
\hline No. & Nama Informan & Umur & Pendidikan & Keterangan \\
\hline 1. & SM (Pasien) & 48 & SMA & Bersedia melakukan perawatan luka \\
2. & M (Pasien) & 45 & DIII & Bersedia melakukan perawatan luka \\
3. & M (Perawat IGD) & 47 & SPK & Pasien tidak disiplin mengikuti aturan \\
4. & M (Perawat IGD) & 41 & S1 & Pasien tidak disiplin mengikuti aturan \\
5. & D (Dokter Koordinator) & - & S1 & Pasien tidak disiplin mengikuti aturan \\
6. & Y (Kepala Puskesmas) & - & S1 & Pasien tidak disiplin mengikuti aturan \\
\hline
\end{tabular}

Tabel 3

Hasil Kesimpulan Indepth Interview Fasilitas tentang Perawatan Luka

\begin{tabular}{lllll}
\hline No. & Nama Informan & Umur & Pendidikan & Keterangan \\
\hline 1. & SM (Pasien) & 48 & SMA & Fasilitas baik obat, alat dan tenaga medis tersedia \\
2. & M (Pasien) & 45 & DIII & Fasilitas baik obat, alat dan tenaga medis tersedia \\
3. & M (Perawat IGD) & 47 & SPK & Fasilitas baik obat, alat dan tenaga medis tersedia \\
4. & M (Perawat IGD) & 41 & S1 & Fasilitas belum maksimal untuk perawatan luka
\end{tabular}


$\begin{array}{lllll}\text { 5. } & \mathrm{D} \text { (Dokter Koordinator) } & - & \mathrm{S} 1 & \text { Fasilitas belum maksimal untuk perawatan luka } \\ \text { 6. } & \mathrm{Y} \text { (Kepala Puskesmas) } & - & \mathrm{S} 1 & \text { Fasilitas belum maksimal untuk perawatan luka }\end{array}$

PEMBAHASAN

\section{Pengetahuan}

Seluruh Informan tidak mengetahui jika luka tidak ditangani maka akan terjadi amputasi. Ulkus diabetes disebabkan oleh beberapa faktor yaitu neuropati, trauma, deformitas kaki, tekanan tinggi pada telapak kaki dan penyakit vaskuler. Pemeriksaan dan klasifikasi ulkus diabetik yang menyeluruh dan sistematik dapat membantu memberikan arahan yang adekuat. Ulkus diabetik dapat juga disebabkan oleh tekanan yang terus menerus atau adanya gesekan yang mengakibatkan kerusakan pada kulit Gesekan bisa mengakibatkan terjadinya abrasi dan merusak permukaan epidermis kulit Secara fisiologis penyembuhan luka terjadi dengan cara yang sama pada semua pasien, dengan sel kulit dan jaringan. kembali secara cepat atau lambat. Informan 3 tidak mengikuti seminar maupun pelatihan perawatan luka moderen sehingga faktor pengetahuan akan menghambat proses penyembuhan luka ulkus diabetikum. Informan 4 dan 5 telah mengikuti seminar perawatan luka namun informan 5 tidak pernah mengikuti pelatihan perawatan luka moderen.

Menurut Notoatmojo (2014), Pengetahuan merupakan hasil dari tahu, dan ini terjadi setelah orang melakukan pengindraan terhadap suatu obyek tertentu. Pengindraan terjadi melalui pancaindra manusia, yakni indra penglihatan, pendengaran, penciuman, rasa, dan raba. Sebagian besar pengetahuan manusia diperoleh melalui mata dan telinga (10).

$$
\text { Pemahaman Perawat yang benar }
$$

tentang teknik perawatan luka terkini akan meningkatkan kualitas pelayanan kesehatan. Banyak teknik perawatan luka dikembangkan diberbagai rumah sakit. Perawatan luka dewasa ini, cenderung menggunakan metode balutan kasa, Basah Kering digunakan khusus untuk debridemen pada dasar luka, normal saling digunakan untuk melembabkan kasa, kemudian dibalut dengan kasa kering. Ketika kasa lembab menjadi kering, akan menekan permukaan jaringan, yang berarti segera harus diganti dengan balutan kering berikutnya (11).

$$
\text { Pengetahuan menjadi salah satu }
$$
faktor yang sangat mempengaruhi perilaku seseorang atau masyarakat terhadap kesehatan secara umum pengetahuan terhadap Informan 1 dan informan 2 kurang . Pengetahuan semua Informan tentang perawatan luka kurang ini disebabkan karena kurangnya pengetahuan tentang penyakit dan perawatan luka atau bisa dikarenakan 
informan hanya terfokus dengan penyakit diabetes melitus yang dideritanya tanpa mengetahui jika penyakitnya akan sangat berpengaruhi terhadap penyembuhan luka yang diderita informan. Informan 3 tidak mengikuti seminar maupun pelatihan perawatan luka moderen sehingga faktor pengetahuan akan menghambat proses penyembuhan luka ulkus diabetikum. Informan 4 dan 5 telah mengikuti seminar perawatan luka namun informan 5 tidak pernah mngikuti pelatihan perawatan luka moderen.

\section{Sikap}

Hasil penelitian mengenai sikap Informan terhadap luka yang dialaminya di temukan rasa khawatir serta rasa takut kehilangan jari kaki akibat luka yang sulit sembuh sehingga informan merasa percaya dirinya hilang karena kehilangan salah satu jari kakinya yang telah diamputasi. Sikap informan 3 dan informan 4 serta informan lain merasa khawatir dalam merawat luka ulkus diabetikum berhubung pasien yang di rawat tidak disiplin dalam kunjungan ke puskesmas untuk mengganti balutan luka.

Hal ini sesuai dengan Sikap merupakan tanggapan atau reaksi seseorang terhadap suatu objek, dalam bentuk positif atau negatif yang dapat berupa rasa suka atau tidak suka, setuju atau tidak setuju. Sikap merupakan kesiapan untuk bereaksi terhadap suatu objek dengan cara tertentu serta respon evaluatif terhadap pengalaman kognitif, reaksi afektif, kehendak dan perilaku. Sikap dapat berupa rasa suka tidak suka, mendekati atau menghindari situasi, orang, benda, suatu kelompok atau aspek lingkungan yang dapat dikenal lainnya termasuk gagasan abstrak dan kebijakan sosial. Sikap adalah bagaimana pendapat atau penilaian seseorang terhadap hal yang terkait dengan kesehatan, sehat, sakit, dan faktor yang terkait dengan faktor risiko kesehatan (8).

\section{Pendidikan}

Hasil penelitian mengenai tingkat pendidikan terakhir informan, Informan yang paling tinggi tingkat pendidikannya adalah sarjana dan informan yang pendidikan terakhirnya smu. Pendidikan informan sangat berpengaruh terhadap pengetahuan informan mengenai perawatan luka terutama informan mengalami diabetes melitus begitu juga dengan informan lainnya.

Tingkat pendidikan seseorang signifikan akan memengaruhi pola respon. Semakin tinggi pendidikan seseorang maka akan menimbulkan respon kesehatan yang baik, yaitu dalam pemilihan pelayanan kesehatan maupun praktik perawatan dirinya sehingga dapat meningkatkan derajat kesehatan (12). 


\section{Fasilitas Kesehatan}

Dari hasil penelitian didapatkan

bahwa ketersediaan fasilitas untuk

perawatan luka secara umum sudah

menunjang karena Standar Prosedurnya

sudah ada tapi untuk perawatan Luka

Diabetikum (belum, karena belum punya standar, fasilitas mana yang akan dilengkapi.

Menurut Notoatmodjo, (2003) untuk mewujudkan sikap menjadi suatu perbuatan nyata diperlukan faktor pendukung atau kondisi yang memungkinkan antara lain fasilitas. Fasilitas merupakan suatu faktor pendukung dari tingkat kesehatan yang terwujud dalam lingkungan fisik. Sarana kesehatan berfungsi untuk melakukan upaya kesehatan dasar atau upaya kesehatan dan kesehatan penunjang (13).

Dari hasil penelitian, menurut peneliti fasilitas merupakan suatu faktor pendukung dari tingkat kesehatan yang terwujud dalam lingkungan fisik. Tersedia atau tidak tersedianya fasilitas atau sarana kesehatan termasuk juga kelengkapan dalam perawatan Luka Diabetikum (Gangren). Berdasarkan hasil penelitian yang terungkap diatas, menunjukkan fasilitas juga dapat dimasukkan dalam salah satu faktor yang mempengaruhi peran perawat dalam melakukan perawatan Luka (14).

\section{KESIMPULAN}

Dari hasil penelitian tentang pengaruh tindakan perawatan luka terhadap proses penyembuhan luka ulkus diabetikum pada pasien DM di Puskesmas Kota Rantau Prapat tahun 2020, didapat beberapa kesimpulan sebagai berikut :

1. Dalam melakukan perawatan luka pengetahuan informan yang kurang pengalaman,pendidikan informan dan sikap informan yang tidak disiplin dalam mengganti balutan luka sangat mempengaruhi proses penyembuhan luka ulkus diabetikum.

2. Fasilitas pengobatan kurang lengkap ketika luka yang diderita informan mengalami nekrotik atau jarinya menghitam sehingga Informan di rujuk ke Rumah sakit umum RantauPrapat untuk dilakukan amputasi oleh dokter spesialis Bedah'.

3. Pendukung yaitu keluarga, teman maupun petugas kesehatan mempengaruhi dalam keterlambatan dalam perawatan luka yang dialami kedua informan.

\section{UCAPAN TERIMAH KASIH}

Terima kasih peneliti ucapkan kepada 
Kepala Pukesmas beserta dokter, perawat IGD dan staff di Puskesmas Kota Rantau Prapat yang ikut berpartisipasi dan membantu dalam proses penyelesaian penelitian ini.

\section{DAFTAR PUSTAKA}

Kusumaningrum NSD, Asrinigati R. Identifikasi Risiko Diabetic Foot Ulcer (DFU) pada Pasien dengan Diabetes Melitus. J Luka Indones. 2016;

Najatullah IW. Hubungan Kualitas Tidur dengan Kontrol Glukosa Darah Pasien Diabetes Melitus Tipe 2 di Klinik Spesialis Perawatan Luka, Stoma, dan Inkontinensia "Kitamura" Pontianak Tahun 2015. 2015;

Sembiring EE, Simbolon P, Lase E. Pengaruh Senam Kaki Terhadap Penurunan Neuropati pada Pasien dengan Luka Kaki Diabetik di Asri Wound Care Medan. J Mutiara Ners. 2018;114-20.

Rachma N, Andriany M. Studi Kasus: Penggunaan Pembalut Herbal Sebagai Absorbed Pada Modern Dressing. Keperawatan Komunitas. 2013;1(2):130-4.

Rukmi DK, Hidayat A. Pengaruh Implementasi Modern Dressing Terhadap Kualitas Hidup Pasien Ulkus Diabetikum. 2018;5(Suppl 1):19-23.
Gito, Rochmawati E. Efektifitas Kandungan Modern Wound Dressing Terhadap Perkembangan Bakteri Staphylococcus Aureus Effectiveness of Modern Wound Dressing on the Growth of Staphylococcus Aureus Bacteria. 2018;9:88-99.

Kartika RW. Perawatan Luka Kronis dengan Modern Dressing. Teknik. 2015;42(7):546-50.

Wiyarini N. Makna Profesionalisme Perawat dalam Persspektif Pasien (Pendekatan Kualitatif). Bauk I, editor. Procedling Semin Nas Pesat. Pertama. 2005;

Rachmawati IN. Pengumpulan Data Dalam Penelitian Kualitatif: Wawancara. J Keperawatan Indones. 2007;1.

10. Putri A. Hubungan Pengetahuan dengan perilaku Perempuan Obesitas tentang Pencegahan Risiko Penyakit Akibat Oberistas di Desa Slahung Wilayah Kerja Puskesmas Slahung Ponorogo. 2018;10-34.

Somayeh M. سالمندى دوران تغييرات. 1397; Available from: http://beytoote.com/wedlock/zojnemune/changes8-old-age.html

Putri AE, Fitriangga A, Natalia D. Studi Kualitatif Perilaku Mencari Kesehatan 
Jurnal Bidang Ilmu Kesehatan

dan Praktik Perawatan Diri pada Penderita Filariasis di Kecamatan Teluk Pakedai. J Cerebellum. 2019;5.

Febrianti A. Peran Perawat dalam Perawatan Luka Diabetikum (Gangren) di Ruang Dahlia Rumah Sakit. 2014;
Hechavarría, Rodney; López G. 済無. J Chem Inf Model [Internet]. 2016;53(9):168999. Available from: http://repository.umy.ac.id/bitstream/ handle/123456789/2512/g. $B A B$ 3.pdf?sequence $=7 \&$ isAllowed $=y$ 